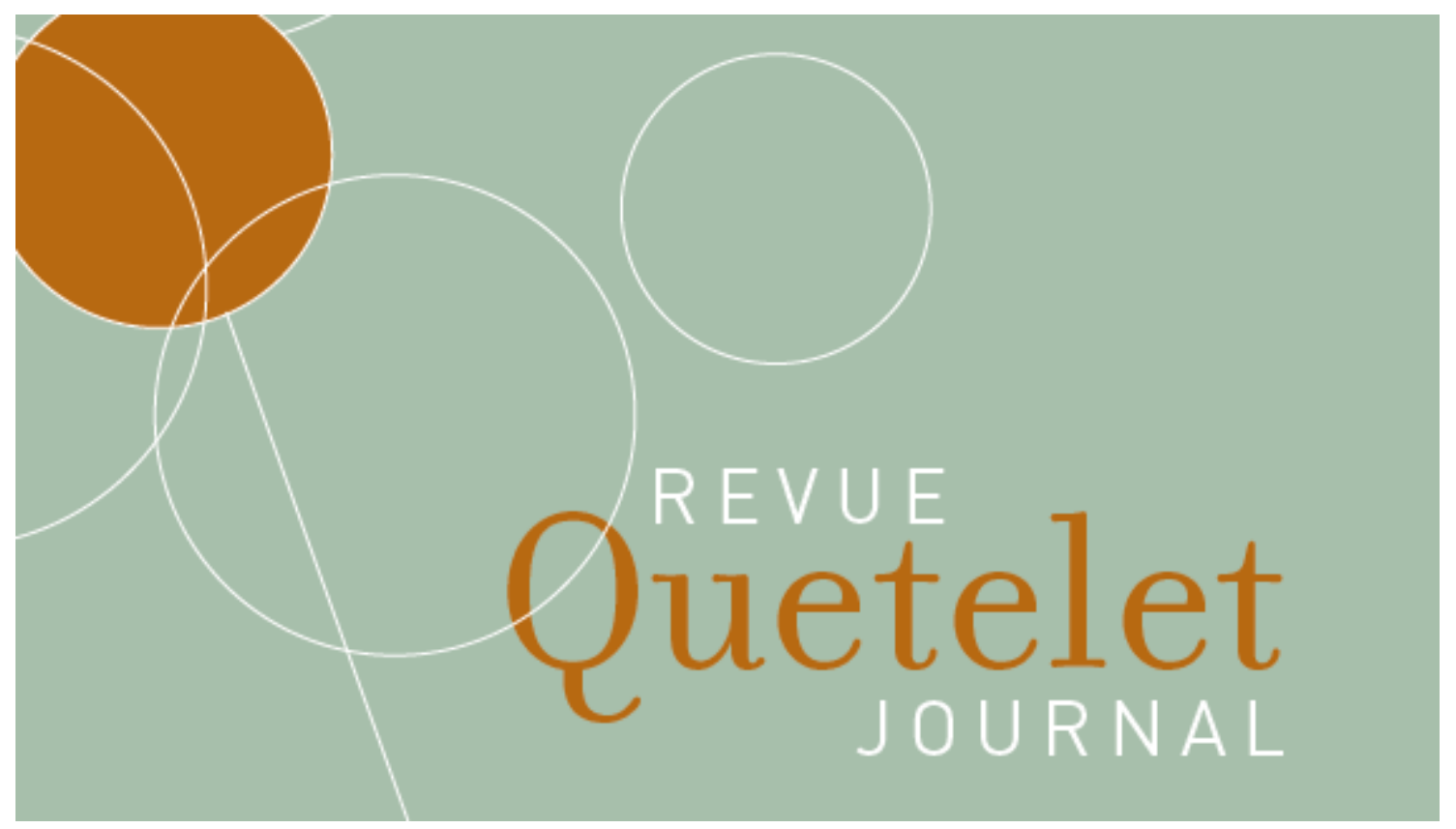

Vol. 5, n² 1, avril 2017, pp. 7-31

DOI : 10.14428/rqj2017.05.01.01

ISSN: 20349378

\title{
Low fertility, childlessness and family changes in the first half of the 20th century in France and Belgium
}

Sandra Brée, Thierry Eggerickx, Jean-Paul Sanderson

(C)2017 Sandra Brée, Thierry Eggerickx, Jean-Paul Sanderson

This work is licensed under a Creative Commons Attribution-NonCommercial 4.0 International License. You can share, adapt the material for non-commercial purposes provided that you give appropriate credit and indicate if changes were made. For details see https://creativecommons.org/licenses/by-nc/4.0/

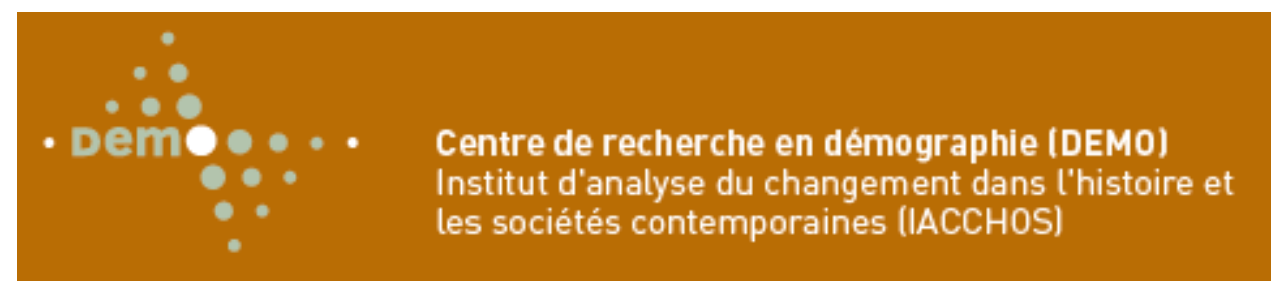




\title{
Low fertility, childlessness and family changes in the first half of the 20th century in France and Belgium
}

\author{
SANDRA BRÉE \\ THIERRY EGGERICKX ${ }^{1}$ \\ JEAN-PAUL SANDERSON ${ }^{1}$
}

\begin{abstract}
Résumé
Au cours de l'entre-deux-guerres, la fécondité a chuté à des niveaux très faibles dans de nombreux pays d'Europe occidentale, presque toujours en dessous du niveau de remplacement. Ce phénomène reste pourtant assez peu étudié et c'est pour apporter de nouveaux éléments à sa compréhension que cet article se penche sur la taille de la famille en France et en Belgique pour les générations de femmes nées entre 1872 et 1931 (en distinguant les femmes en fonction de leur état civil), révélant le rôle important de l'infécondité et des petites familles dans les très faibles niveaux de fécondité observés. Un accent particulier est également mis sur le calendrier de la formation de la famille révélant que les très faibles niveaux de fécondité de l'entredeux-guerres peuvent être expliqués, au moins en partie, par une modification du calendrier de la fécondité.
\end{abstract}

\section{Mots-clé}

Fécondité, infécondité, taille des familles, entre-deux-guerres, analyse longitudinale, France, Belgique.

\begin{abstract}
During the interwar period, fertility dropped to very low levels in many western European countries, almost always below the replacement level but not much is known about this phenomenon. To bring new features, this paper focuses on family size in France and in Belgium for cohorts of women born between 1872 and 1931 (distinguishing women according to their marital status), revealing the important role of childlessness and small families in the strong decline in fertility. A particular focus is then placed on the timing of family formation revealing that the very low levels of
\end{abstract}

1. Centre de recherche en Démographie, Université catholique de Louvain (UCL), Louvain-la-Neuve, Belgique. 
fertility of the interwar period can be explained, at least in part, by a modification of the timing of fertility.

\section{Keywords}

Fertility, childlessness, family size, interwar period, longitudinal analysis, France, Belgium.

\section{Introduction}

Between 1920 and 1940, fertility dropped to very low levels in many western European countries, almost always below the replacement level (Sardon, 1990). These low fertility levels mark the end of the first demographic transition in most western countries (Caldwell, 2008) and they took place within a highly unstable socioeconomic and political context characterised by the Great Depression and the emergence of totalitarian regimes.

The latter part of the first demographic transition process has rarely been studied closely, with most studies focusing on its beginning (Bengtsson, Dribe, 2014; Schellekens, Van Poppel, 2012). Some authors interpret the low levels of fertility in the 1920s and 1930s as a mere continuation of decreases that began a few decades earlier, regarding individualism, consumerism or secularisation as their main determinants (Van Bavel, 2010). Other authors hypothesise a negative effect on fertility due to the economic crisis and its social consequences (such as unemployment, falling salaries, and the increasing «cost» of raising children) (Caldwell, 2008). To try to better understand this phenomenon, this paper adopts a new approach: it focuses on family size, thus revealing the important role of childlessness and small families in the strong decline in fertility.

The article specifically focuses on two countries: France and Belgium. In terms of fertility, France and Belgium, from the end of the 19th century to the start of the 20th, represent contrasting cases. France is known for being the first country where fertility declined, while in Belgium, the decrease took place later and unfolded more rapidly. Belgium and France were also heavily affected by the First World War. In France, the number of civilians and combatants killed was extremely high (Vallin, 1973; Rohrbasser, 2014), and most of these were young men, a phenomenon which can have a strong effect on nuptiality and fertility. Belgium was a major battlefront zone during the conflict, but the number of Belgian deaths was much lower. In terms of the economic crisis of the 1930s, even if the GDP was a little higher in Belgium than in France (Appendix 1), 
trends in both countries were very similar. Finally, the socioeconomic context differed between the two countries, especially in the areas of urbanisation, industrialisation and secularisation.

To deepen our understanding of the low levels of fertility during the interwar period, we reconstruct the evolution of lifetime fertility distribution according to the number of children for cohorts of women of childbearing age during this period. This analysis is done using population censuses and surveys and is based on a retrospective approach that allows for the measurement of completed fertility and parities. As the analysis is conducted at the aggregate level, our explanations of the phenomena at stake do not take into account individual determinants. Following a description of our data sources and methodology, the parities measured for cohorts of women born between 1872 and 1931 are presented and discussed to understand the role of family size in fertility trends. The analysis is conducted first for all women, then for ever-married women. Finally, particular focus is placed on the timing of family formation to determine what new insights calendar indicators can bring. This examination of the distribution of parities and the timing of fertility gives rise to a discussion of the role of events, such as the First World War and the economic crash of the 1930s, on the low fertility levels reached during the interwar period.

\section{The low fertility cohorts in France and Belgium}

Despite the implementation of state policies - in the form of both restrictions ${ }^{2}$ and incentives ${ }^{3}$ - designed to encourage fertility and rebuild the population in response to the heavy losses incurred during the First World War ${ }^{4}$ and the deficit of births during the war, women who had their child(ren) between 1920 and 1940 were among the least fertile of the 20th century. This points to a gap between the implementation of laws

2. In France, a 1920 law criminalised abortion and prohibited the promotion of birth control, and a 1923 law toughened penalties for abortion. In Belgium, a 1920 law amended the Criminal Code to punish abortion practices as well as the promotion of contraception and abortion.

3. In France, the creation of Mother's Day in 1932 and of family allowances were extended in 1939. Regarding Belgium, see Piette and Gubin (2002); regarding France, see De Luca Barrusse (2008).

4. In France, an estimated 1.4 million soldiers were killed, and in Belgium, the estimates hover around 50'000 (Rohrbasser, 2014). 
and the behaviours these are intended to affect (Cova, 1997), since these laws had no apparent effect on the birth rate (McLaren, 1990). Although the postwar context could have led to an increase in fertility (as it did with the baby boom after the Second World War), this was not the case, or was only so very briefly as a simple recovery effect. This is all the more striking as natalist ideologies and the nationalisation of women's bodies were prominent in the interwar period (Thébaud, 1992): while many women tasted independence during the First World War, after it ended they reverted to being seen as primarily mothers - «each sex regains its place» (Rebreyend, 2008, p. 27; see also McLaren, 1990). The love marriage was embraced as a means of coping with the war in the 1920s and the economic crisis in the 1930s (Rebreyend, 2008): love was in the air between the two wars, as were happiness and everyday pleasures (Rebreyend, 2008). Despite all these factors that could have led to higher levels of fertility, having a large number of children was not a feature of the interwar period. This paper analysis the demographic behaviours of women who had their children during the interwar period to try to bring new elements of explanation.

In Belgium, women born between 1897 and 1901 gave birth to an average of 1.9 children, and it was only with the cohorts born between 1912 and 1916 that the threshold of two children was again exceeded (Figure 1). Even if the Belgian levels were very low during the interwar period, they were not exceptional when compared with other European countries. In Norway, Sweden, Switzerland and England, lifetime fertility dropped to fewer than two children per woman for cohorts born between 1904 and 1907 (Sardon, 1990). The fact that fertility trends in these nonbelligerent (or non-war-affected) countries took the same form as in wartorn countries (such as France and Belgium) could mean that the First World War did not have a great impact on fertility or, at least, that its impact is not visible on the lifetime fertility indexes.

In France, lifetime fertility levels were little higher than in Belgium, never going below two children per woman, which is the minimum reached by the cohort born in 1895 (Brée, 2017). The timing was also different as the rise in lifetime fertility affected cohorts born earlier than in other European countries, such as Belgium (Festy, 1979; see also Appendix 2). Cross-sectional indicators show a slight recovery in fertility in the mid1930s (Depoid, 1941) which has not been noted by contemporary scholars (Sardon, Calot, 1997) and that could be interpreted as the first signs of the baby boom. Despite fertility behaviours that are more in line with those of nearby countries than with the beginning of the transition, it 
seems that France still followed a specific path (Bardet, 1998), at least before the Second World War.

FIgURE 1 Lifetime fertility in selected European countries in the first half of the 20th century

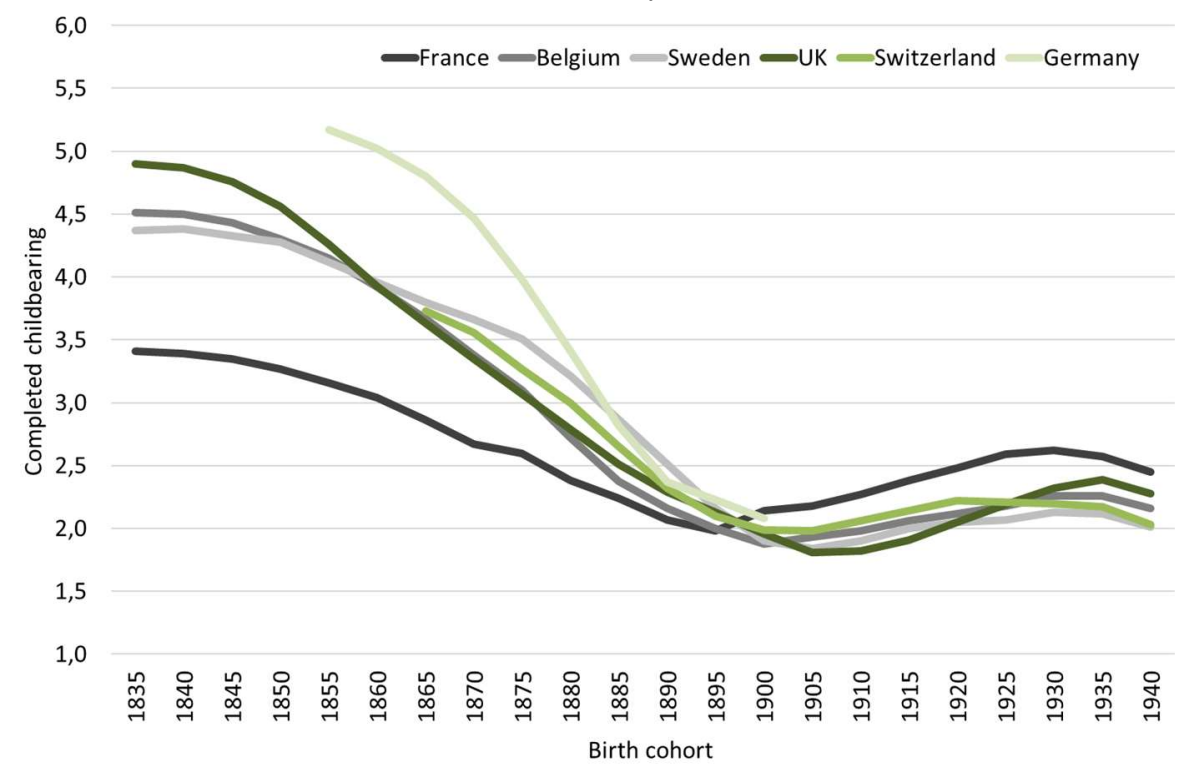

Sources: Sweden, UK, Switzerland, Germany and Belgium (1835-1880 cohorts): Festy, 1979; Belgian and French cohorts, 1880-1940: authors' calculations (Brée et al., 2016a; Brée, 2017).

Are these lows in fertility due to an overall decline in family size, or can they be more particularly a consequence of an increase in childlessness or of very low levels of fertility? This is the question we will try to answer in the first part of this article. We look first at all women and then at evermarried women mothers to determine whether discrepancies appear in the behaviours of these two groups. Childlessness must be understood here as overall childlessness, that is to say, the fact of remaining childless at the end of reproductive life (women aged at least 45 years old at the time of the survey or census), and small families are defined here as women who have had only one child born alive.

In practice, these very low fertility rates may reflect one of the following scenarios:

a a significant reduction in higher parities while childlessness stagnates;

b an increase in childlessness and small families, while large families remain stable; 
c a parallel evolution of parities, namely a reduction in higher parities coupled with an increase in childlessness and small families.

Some authors have found for the early 20th century that childlessness was greatest in the times and places where fertility control was most evident (Morgan, 1991; Poston, Trent, 1982; Spencer, 1983) ${ }^{5}$. However, Australian data provides moderate support to the hypothesis that higher levels of childlessness among married women are associated with smaller families (Rowland, 2007). The consideration of women's lifetime fertility alongside their number of children will allow us to shed new light on this question.

Another line of inquiry will deal with the link that can be drawn between childlessness and small families. Do the latter represent failed attempts at childlessness or, conversely, a postponement of childbearing that ultimately leads to having only one child? For women born in the early 20th century in Australia (Rowland, 2007) and in the United States (McLaughlin et al., 1988), the highest proportions of married women with one child occur in the same birth cohorts as those with peak proportions of childlessness. The later fall in the proportions of women with only one child matched the fall in the proportions of married women remaining childless. According to Rowland (2007), this association was expected, especially because the one-child family has never been a popular family size and suggests uncompleted, or unusually limited, family-building goals. Rebreyend (2003) claims, on the contrary, that the arrival of the first child for married women is often desired, whereas subsequent ones are more often less welcome.

The second part of this article will focus on the timing of family formation by considering age at first marriage along with age at first birth according to the number of children, to understand whether postponement can explain childlessness and small families. Indeed, postponement of marriage is often viewed as the cause of childlessness when in fact the cause is couples waiting too long to have children, which in many cases leads to permanent childlessness (Mattessich, 1979; Morgan, 1991; Hagestad, Call, 2007; Rowland, 2007). According to several authors, couples can also deliberately space births during difficult periods to reduce the burden on the household budget (Van Bavel, 2003; Van Bavel, Kok, 2004, 2010) or even choose not to have children (Toulemon, 1995). As many scholars of

5. Some authors point out that venereal diseases - syphilis and gonorrhea in particular - can cause temporary or permanent infertility (Szreter, 2014). The prevalence of venereal diseases is high after the First World War (due to the massive attendance of prostitutes by soldiers) and these diseases may therefore have contributed to the low fertility observed in making (usually temporarily) couples sterile (Cahen, Minard, 2015). 
the interwar period (Van Bavel, Kok, 2010), Benninghaus (2014) ascribed this strong birth control to individualisation, secularisation and the priority newlywed couples gave to career development and a comfortable lifestyle. While these studies have all focused mainly on childlessness, one may also ask whether the postponement of marriage and first birth might also have been the cause - or one of the causes - of one-child families.

Finally, the drop in the $1920-1940$ period is usually explained as a temporary reaction to the exceptional conditions of the interwar period (Brée et al., 2016b), namely the deep economic and political crisis and the threat of the outbreak of another war (Lesthaeghe, 1995; Caldwell, Schindlmayr, 2003; Frejka, Sardon, 2004; Sobotka, 2004). According to Van Bavel (2010), virtually no demographer living between the wars attributed the very small family sizes and low fertility to economic stagnation or crisis. Rather, leading demographers linked low fertility to processes that now tend to be associated with the Second Demographic Transition, including secularisation, individualisation, rising consumerism and women's emancipation, which together can be summarised as modernisation (Van Bavel, 2010). Landry (1934), for instance, situates his discussion in a context of rising well-being, stimulated by innovation in technology and industry, with numerous inventions of household consumer goods which incited people to raise their consumption aspirations. What can shifts in parities and the timing of family formation teach us about the impact on fertility of these two major events - World War I and the economic crisis - of the early 20th century?

\section{Sources and methodology}

The scarcity of articles on fertility during the interwar period is mainly due to the lack of appropriate data. For one, the use of individual administrative data that is less than 100 years old is not permitted in Belgium and France. In addition, the aggregated data available for census years offer limited opportunities for the detailed study of fertility behavior because they are generally limited to indirect measures (such as the Coale fertility indices) and are often only indicators of intensity indicators.

In this context, a retrospective approach drawing on Belgian censuses and French censuses and Family Surveys opens the way for detailed longitudinal study of fertility over the 20th century. These data are used to reconstruct the entire reproductive life of cohorts of women born from the late 19th century. The reliability of this method has been shown for 
several countries and different sources (Neels, 2006, 2010; Andersson, Sobolev, 2013; Brée et al., 2016a; Van Bavel, 2014).

Belgian censuses $(1961,1981)$ on the one hand, and French censuses and Family Surveys on the other, will be used for this study (Brée et al., 2016a). In these censuses and surveys, each woman was asked about the number of live births she had and the years of birth 6 . From this retrospective information, it was possible to reconstruct the complete reproductive course of women born since the late 19th century, and to know the composition of siblings.

The analysis concerning Belgium is mainly based on data from the 1981 census. This census covered the entire population and includes cohorts born as far back as between 1882 and 1886. However, given the low number of women from the cohort born in 1882-1886 still alive ${ }^{7}$ in 1981, the fertility indices are very erratic. To improve them, when possible, data for this cohort was replaced by the corresponding data from the 1961 census. While we have a sample of one-tenth of the population for the 1961 census, the question about children's birth dates was not asked. In summary, the indices for completed fertility and parities achieved and the parity progression ratio were produced by combining data from both censuses. The analyses of the timing of fertility or family formation will focus solely on the 1981 census data and therefore on the cohorts born in the early 20th century.

The French case is different (Brée, 2017). For the 1931 and 1946 censuses, the question about the number of children women had was asked; these censuses can therefore be used. However, they only include the women born between 1860 and 1886 for the first census (if we consider that the 45th birthday marks the end of the fertility period) and between 1867 and 1901 for the second census. This question was no longer asked in subsequent censuses. Family Surveys were implemented from $1954^{8}$ to analyse the reproductive life of women (and of men since the 1999 survey). These surveys, by definition, do not include the whole population but rather 10 to $20 \%$ of the cohorts 9 . The data for ever-married women

6. For France, the question about number of live births was asked in the census until 1946. Since then, the question has been asked in dedicated Family Surveys (1954, 1962, 1975, 1982, 1990, 1999 and 2011). Detailed estimations of French fertility are given in Brée (2017).

7. Namely, 2'972 women.

8. $1954,1962,1975,1982,1990,1999$ and 2011.

9. The 1954 survey included 52'474 ever-married women born between 1899 and 1908; for 1975, it was 247'000 ever-married women born between 1910 and 1960; for 1982, 310'000 women (single or non-single) born between 1917 and 1963; for 1990, 
are very coherent from one survey to another, but a bit less so for nevermarried women (mostly because never-married women are far less numerous). All these data have allowed Brée (2017) to estimate the fertility of French women for more than one hundred birth cohorts, extending on the work of Festy $(1979,1991)$, Sardon $(1990)$, Toulemon $(1995,2001)$ and Daguet (2002).

Biases attributed to the effects of death and migration, but also errors of memory and non-response, do not seem to affect the results (Brée et al., 2016a). Thus, the method is validated. Nevertheless, using retrospective data from population censuses or dedicated surveys to reconstruct fertility involves risks of substantial bias. First, memory errors may occur in the responses, especially among the older cohorts. Moreover, only a share of the generations concerned is observed in the census. The fertility of women out of observation because of death or migration is not known, which may result in selection bias. Finally, a percentage of the population does not respond to certain questions, and these individuals are not evenly distributed geographically or through the different population groups (age groups, social groups, etc.). Estimates from the French surveys also have some variance since these observe only a share of the population (deemed representative of the French population) and the women surveyed are not the same ones from one survey to the next.

However, the analyses conducted for both countries (Brée et al., 2016a) show that the risk of bias due to memory errors and selection effects are limited. These results confirm the findings of Andersson and Sobolev (2013) for the Swedish population registers and Neels (2006) and Van Bavel (2014) for Belgian censuses. The completed fertility of women calculated from censuses and surveys align remarkably well with those calculated from vital data or estimates obtained from indirect methods. Comparing the fertility of women of the same cohort observed in various censuses or surveys results in minimal differences (around 5\%; Brée et al., 2016a), with exceptions for some of the French regions and in the largest Belgian cities.

340'000 women (all women: single or ever-married) born between 1921 and 1971; for $1999,278^{\prime} 000$ women and 167'000 men (all men and women) born before 1981; and for 2011, 238'000 women and 121'000 men (all men and women) born before 1993. The 1962 survey is no longer transmissible. 


\section{Childlessness and small families in Belgium and France during the interwar period}

\section{The distribution of women by parity: the importance of childlessness}

The low levels of lifetime fertility (Figure 1) are largely due to very high levels of childlessness, especially in Belgium. Indeed, childlessness reaches 26 to $30 \%$ for women born between 1882 and 1901, the cohorts who had most of their children born during the First World War and the interwar period (Figure 2). For the same cohorts in France, 21 to $26 \%$ of women remained childless. These levels are high compared to the rest of the century, but they are not exceptional in comparison with other western countries like Germany (26\% childlessness for the cohort born 19001904, Dorbritz, Schwarz, 1996), the Netherlands (23\%, Rowland, 2007), the United States (24\%, Morgan, 1991) and Australia (31\%, Rowland, 2007). These countries with high levels of childlessness also were not directly affected by the First World War (such as the Netherlands). The loss of men cannot thus entirely explain the prevalence of and rise in childlessness, especially since the increase in childlessness began with cohorts that were not affected by the war. However, even if the Netherlands was neutral in the war, that does not mean it was not affected by the atmosphere created by the war. In the same way, the United States and Australia, where childlessness was very high, did send men to war but did not experience combat on their own soil.

In Belgium, as in France, the cohorts born in the late 19th and early 20th centuries are the ones with the highest levels of childlessness of the century. For many countries, changes in childlessness are not known for cohorts born before 1900, but the few data available show that the strongest levels of childlessness observed before the baby boom are in Australia and Germany and also for the cohorts born at the turn of the 20th century (Rowland, 2007).

Small families (with only one child) were also numerous in France (23$24 \%$ ) and in Belgium (24-25\%) for the same cohorts. Around half of the women (45-55\%) born between the 1890s and the mid-1910s had no children or only one child. The increase in childlessness and small families for women born in the late 19th and early 20th centuries seems to be an essential component of the decline in fertility and the very low fertility levels observed over the interwar period. 


\section{The parity progression ratio}

In France, as in Belgium, the lowest fertility rates were reached by cohorts of women born at the turn of the 20th century, whose reproductive lives largely unfolded during the interwar period. In more controlled fertility regimes, fertility behaviours are closely correlated with the number of children already born (Festy, 1979). This can be taken into account by calculating the parity progression ratio (PPR), the proportion of women having an additional birth.

FIGURE 2 Lifetime fertility distribution according to number of children ${ }^{10}$ for Belgium and France ${ }^{11}$

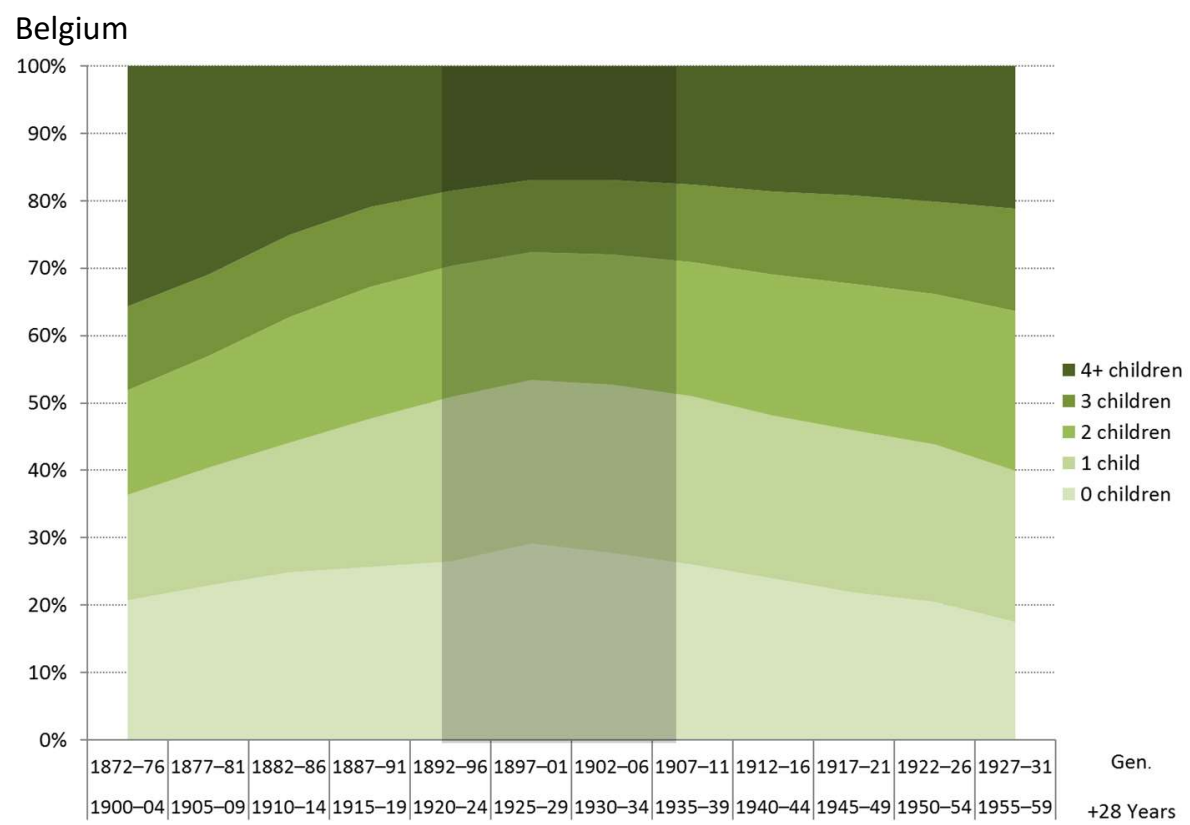
Explanation of the $x$-axis labels: top row: birth date; bottom row: birth date +28 years (mean age at maternity).

10. This takes into consideration all live births.

11. See Appendix 3 for detailed tabulations. 


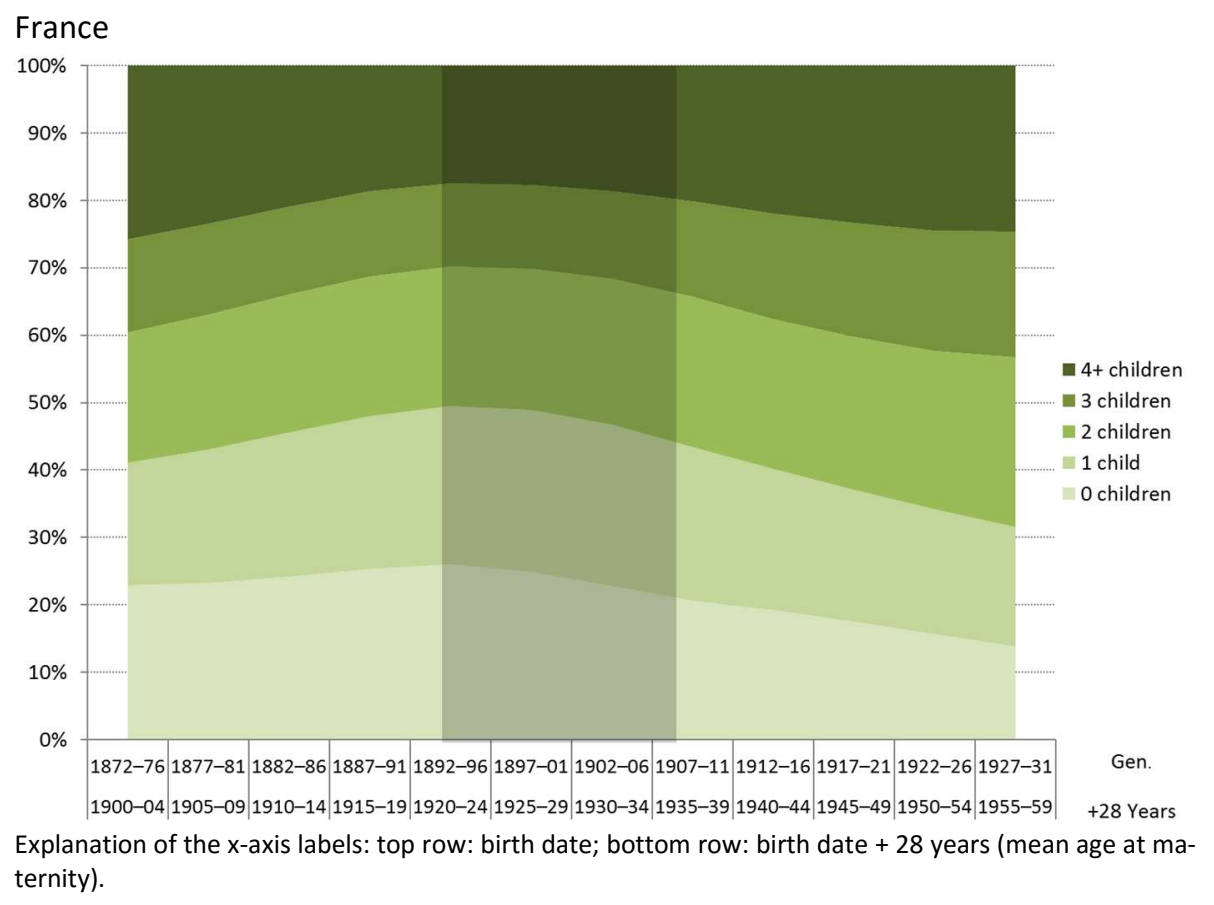

The parity progression ratio allows better characterisation of the specific family patterns for these cohorts, compared with those who preceded them and those who followed them (Figure 3). The PPR $\mathrm{a}_{0}$ expresses, for all women without children, the likelihood of having at least one birth. The PPR $\mathrm{a}_{1}$ is the risk for any woman with one child of having a second one, and so on. The complement to the unity of $\mathrm{a}_{0},\left(1-\mathrm{a}_{0}\right)$, corresponds to the risk of being childless.

As noted above, compared with older and younger cohorts, the cohorts born between 1892 and 1911 are characterised by the lowest probabilities of having a first child. They maintained the trends of previous cohorts but did not correspond with those of the baby boom, for which the risk of remaining childless would drop. 
FiguRE 3 Parity progression ratios for Belgium and France

\section{Belgium}

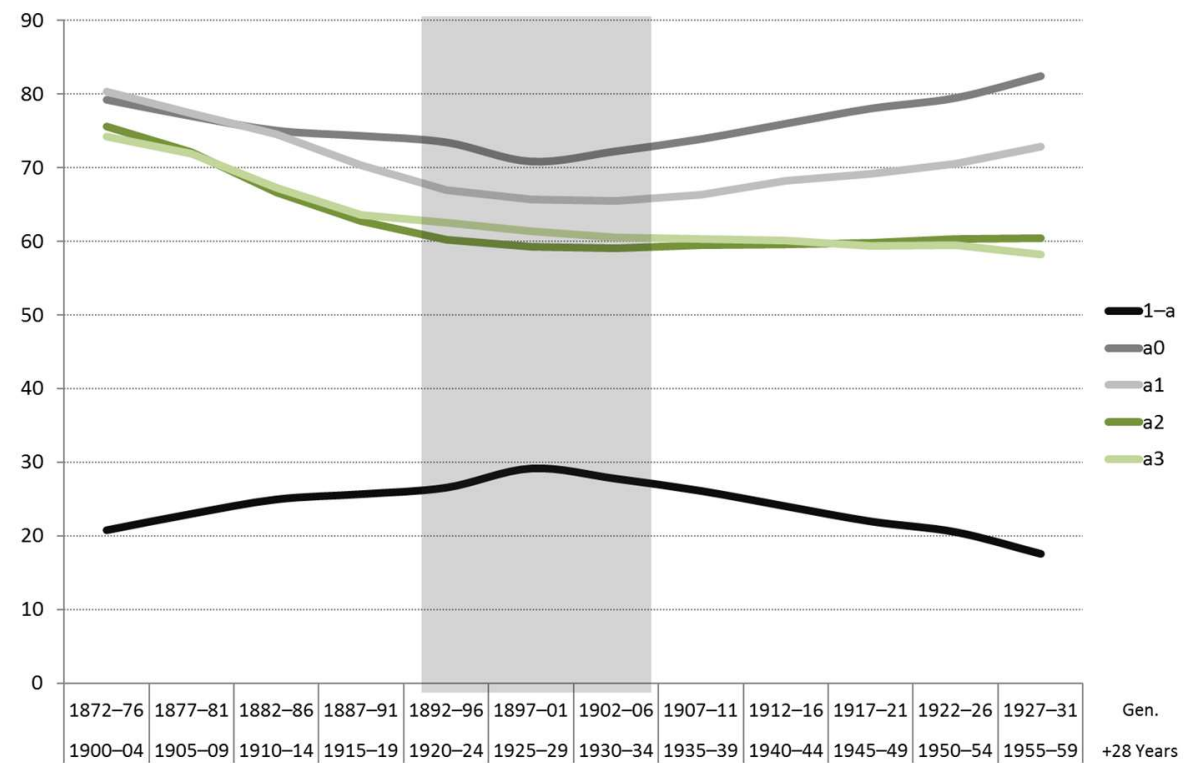

\section{France}

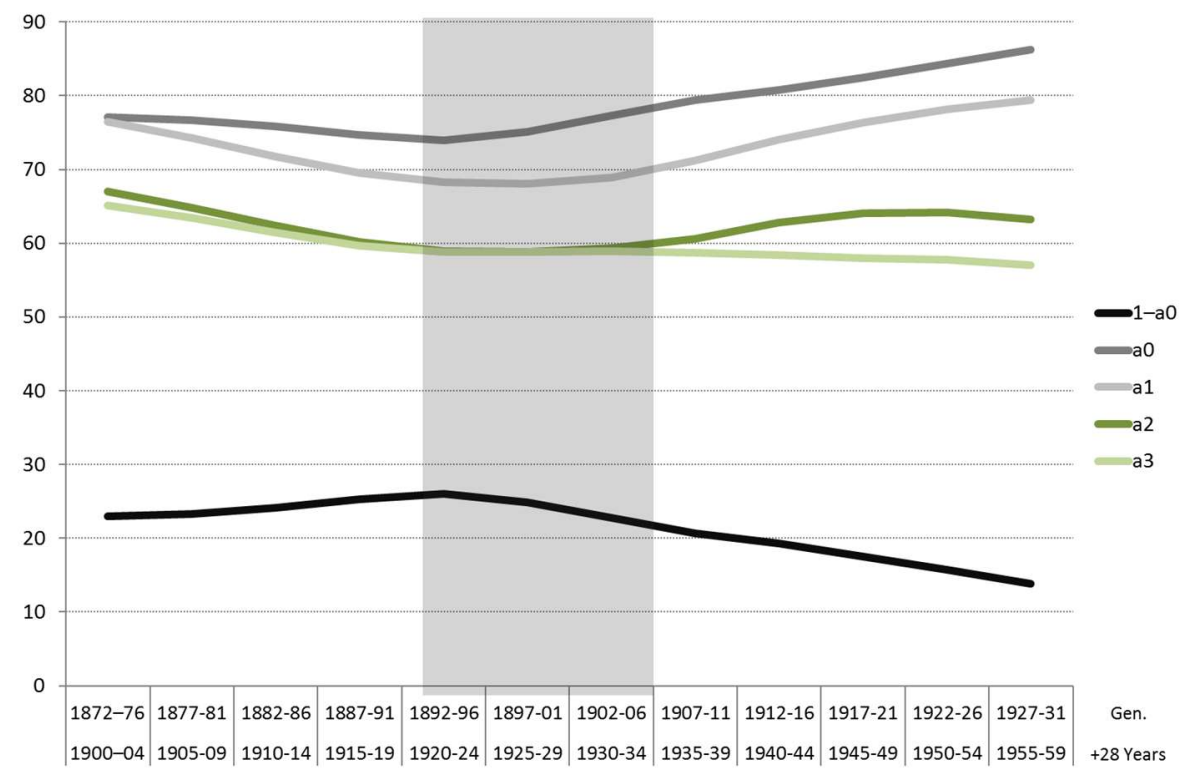

The probability of having a second child $\left(\mathrm{a}_{1}\right)$ also reaches its lowest level for these cohorts, before rising slightly in the Belgian case and more markedly in the French case. For higher achieved parities, the PPRs $\left(\mathrm{a}_{2}\right.$, 
$a_{3}$ ) are lower for these cohorts than for those of their mothers, a shift that would continue.

In summary, these few fertile cohorts maintained the trends initiated by those that preceded them, with lower levels regardless of birth order and, above all, historically high levels of childlessness. For the cohorts to follow, those of the baby boom, childlessness is reduced and families with two or three children are more prominent.

\section{Parities according to marital status}

If we consider ever-married women only (Figure 4), childlessness, as we can expect, is lower. Indeed, because many never-married women did not have any children, childlessness is higher for all women than for evermarried ones only. In France, the gap is higher than in Belgium, especially for the cohorts born in the early 20th century, because never-married women had more children there than in Belgium. Indeed, for those cohorts in Belgium, 97\% of never-married women were childless, around $2 \%$ had one child and around $0.5 \%$ had two children or more. In France, births out of wedlock were more common. Unfortunately, numbers of children born to never-married women are difficult to estimate. Thus, for the cohorts under study in this paper, data are available in the 1946 census, but only for ever-married women. Estimates based on the data for single women are not convincing (Brée, 2017). The 1999 survey allows us to estimate that among never-married women born in the early 20th century, about $85 \%$ never had any child, $11 \%$ only one child and $3 \%$ two children or more; childlessness for never-married women representing around $40 \%$ of overall childlessness in France (Toulemon, 1995; Rowland, 2007). In comparison, the proportion for the same cohorts was about one third in the United States (Morgan, 1991) and Australia (Rowland, 2007) and more than half in the Netherlands (Rowland, 2007). According to Rowland (2007, p. 1'326), «the peak in childlessness within cohorts born around the turn of the century appears to have been due substantially to childlessness within marriage because events had more impact on childbearing than on marriage. Some women, widowed at a young age as a result of the First or Second World Wars, may never have remarried and borne children. Also, because of economic depression and war, married couples who postponed having children until better times risked remaining permanently childless if they delayed too long».

When only considering the ever-married women, it appears that women with only one child were more numerous than childless ones in both 
countries (but, in Belgium, only as of the cohorts born in early 20th century). This fact was obscured by the predictably high proportion of nevermarried women that remained childless. It also shows that childlessness was considerably higher in Belgium than in France when we consider only the fertility of ever-married women ${ }^{12}$. In Belgium, the increase in the two-and-three-children category is also stronger than in France and, most importantly, the decrease in large families (four children or more) is much higher in Belgium. In short, shifts in family size are more radical in Belgium than in France.

To better understand the evolution of childlessness and small families, one can study the timing of family formation by measuring women's mean age at first birth in relation to the total number of children, for evermarried women.

FIGURE 4 Lifetime fertility distribution according to number of children ${ }^{13}$ born to ever-married women, for Belgium and France

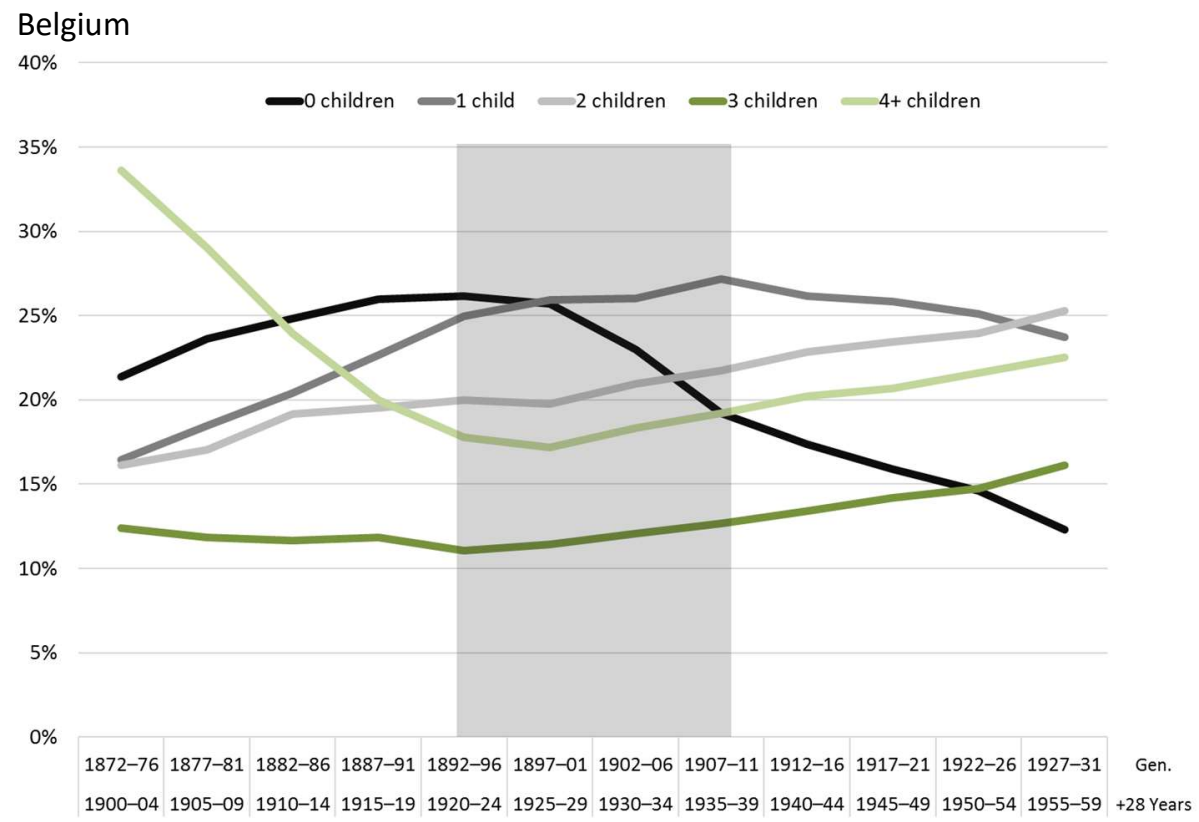

12. Some bias still exists, though, because we are considering not «real» legitimate fertility but the fertility of women ever married at 50 .

13. This takes into consideration all children born alive to these women. 


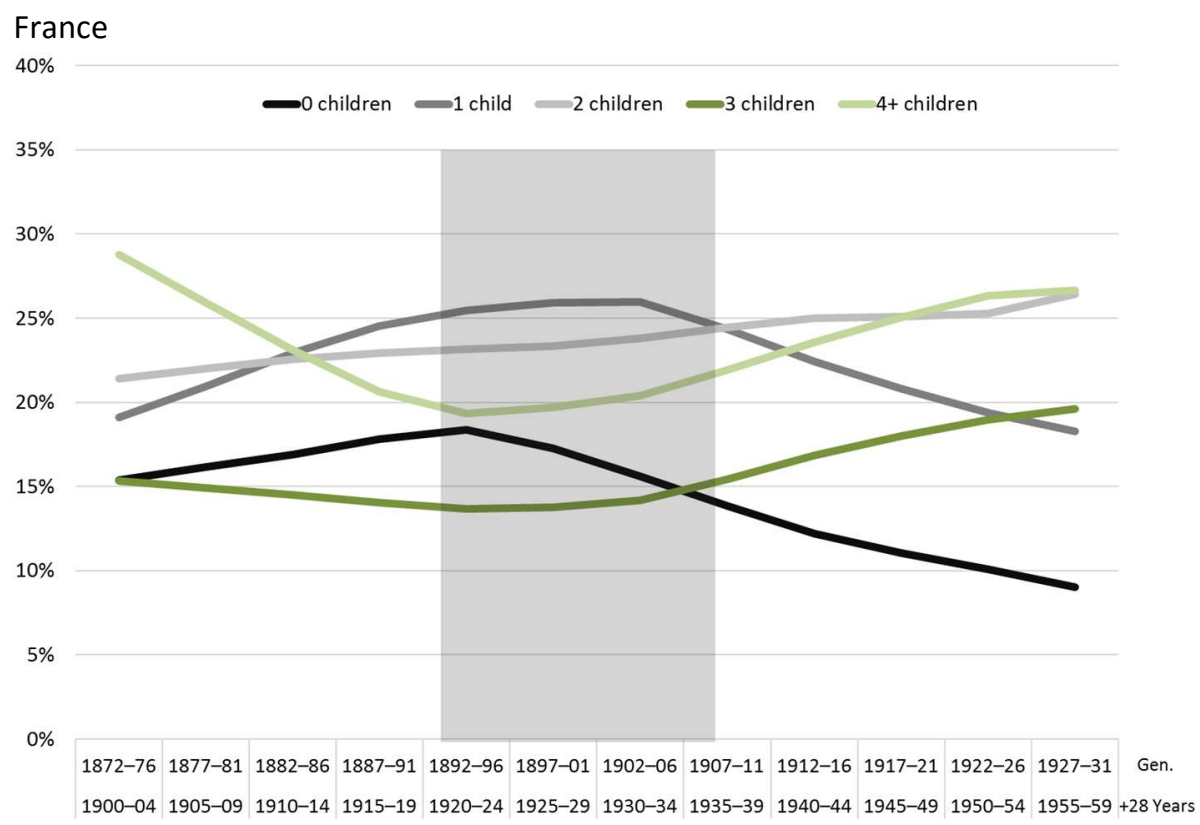

\section{Timing of family formation}

As can be seen in Table 1, women who gave birth to only one child over their lifetime had this child much later than did the women who had two children (almost two years), these in turn having had their children later than those who had three children, and so on. This shows that postponement of the first birth leads to having fewer children, but it is difficult to know whether postponement is intentional (i.e. a conscious contraceptive decision goal) or delayed involuntarily, due, for instance, to the absence of men.

For the interwar period in particular, we can observe an increase in the mean age at first birth for women who only had one child (especially for the cohorts born in 1905 or after) and a decrease for those women who had four children or more ${ }^{14}$. These differences in mean age at first birth

14. For France, two surveys were used to produce Tables 1, 2 and 3: the 1954 survey for the cohorts born between 1899 and 1908 and the 1975 survey for the cohorts born between 1901 and 1925. Even if the greatest increase is observed between 1908 and 1910 - making it difficult to know if the change is real or due to variances in data - the shifts that can be observed between the 1899 and 1908 cohorts (especially the interval between 
could be explained by the differential in mean ages at first marriage, which is lower for women who had four children or more than for those who had three, and so on (Table 2; data only available for France). But the gap between age at first marriage and age at first birth (Table 3) is still greater for women who had only one child, and this gap increases noticeably during the interwar period, especially for women who had one or two children. This can indicate a voluntary postponement of the first birth after marriage.

TABLE 1 Mean age at first birth in relation to number of children born to ever-married women, for France and Belgium

\begin{tabular}{|c|c|c|c|c|c|}
\hline & & 1 child & 2 children & 3 children & 4 children and + \\
\hline \multirow{3}{*}{ Belgium } & 1900-1904 & 26.8 & 25.2 & 24.7 & 24.4 \\
\hline & 1905-1909 & 27.0 & 25.3 & 24.8 & 24.3 \\
\hline & $1910-1914$ & 27.4 & 25.7 & 25.0 & 24.5 \\
\hline \multirow{3}{*}{ France } & 1899-1903 & 26.6 & 24.8 & 24.0 & 23.2 \\
\hline & 1904-1908 & 26.7 & 24.7 & 24.1 & 22.9 \\
\hline & $1910-1914$ & 27.3 & 25.2 & 24.3 & 23.1 \\
\hline
\end{tabular}

Sources:France: for 1899 to 1908 cohorts: 1954 Family Survey; for 1910 to 1914 cohorts: 1975 Family Survey; Belgium: 1981 census.

Table 2 also indicates that French women who remained childless had their first marriage almost four years (3.7) after those who had only one child and 4.4 years after all mothers, which is coherent with results for Britain (Anderson, 1998) and the Netherlands (Van Bavel et al., 2008). Cross-national data show that, in the United States, among women marrying in their early thirties, at least $10 \%$ remained childless, and often the figure was greater than 20\% (Spencer, 1983). In France, for the women born between 1899 and 1908 and who married between ages 30 and 34, 33 to $44 \%$ remained childless. Stated otherwise, among women who married at age 30 or older, the proportion remaining childless was about 4.5 times higher than among those who married earlier. In comparison, this proportion is less than 4 in Germany (Schwarz, 1986).

Postponement of first birth should have led to a drop in fertility, yet fertility rose. The explanation lies in the later births. Indeed, women born in 1910 who had their first child during the economic crisis went on to participate in the baby boom. 
Shifts in the different parities do not seem to be directly affected by changes in age at marriage and at first birth as their timings do not correspond (the increase observed for age at first birth and for the interval between marriage and first birth appears with the cohorts born around 1905). We can even say that despite a postponement of first marriage and first birth, fertility increased for the cohorts born around 1900.

TABLE 2 Mean age at first marriage according to number of children for ever-married women in France

\begin{tabular}{|l|c|c|c|c|c|}
\hline & 0 children & 1 child & 2 children & 3 children & 4+ children \\
\hline $1899-1903$ & 27.3 & 24.0 & 23.2 & 22.8 & 22.6 \\
\hline $1904-1908$ & 27.3 & 23.6 & 23.0 & 22.7 & 22.3 \\
\hline $1910-1914$ & 27.5 & 23.7 & 22.7 & 22.5 & 21.8 \\
\hline
\end{tabular}

Sources: For 1899 to 1908 cohorts: 1954 Family Survey; for 1910 to 1914 cohorts: 1975 Family Survey.

TABLE 3 Interval between mean age at first marriage and mean age at first birth in relation to number of children born to ever-married women in France

\begin{tabular}{|l|c|c|c|c|}
\hline & 1 child & 2 children & 3 children & 4+ children \\
\hline $1899-1903$ & 2.7 & 1.6 & 1.1 & 0.6 \\
\hline $1904-1908$ & 3.1 & 1.7 & 1.3 & 0.6 \\
\hline $1910-1914$ & 3.6 & 2.5 & 1.9 & 1.2 \\
\hline
\end{tabular}

Sources: For 1899 to 1908 cohorts: 1954 Family Survey; for 1910 to 1914 cohorts: 1975 Family Survey.

\section{Conclusion}

This article's primary aim was to understand the impact of childlessness and one-child mothers on the very low levels of fertility observed for the cohorts of women in Belgium and France who had - or did not have their children during the interwar period. For both countries, cohorts of women whose most fertile period occurred during this period are characterised by high levels of childlessness (especially in Belgium when we only consider ever-married women) and small families (with one child only) but also a strong decrease in large families of four children or more. This validates scenario $c$ described in the first section.

The second aim was to understand the role of the timing of fertility on changes in fertility. In summary, two phenomena stand out regarding the timing of the family formation: first, a postponement of marriage for 
childless women, and second, a postponement of first birth, especially among women who had only one child. These results point to several conclusions and issues. Childlessness seems to be a consequence, at least in part, of a postponement of first marriage, but it is difficult to know whether or not this postponement is voluntary. The traditional view is that couples delay marriage until they have the financial means to live as they want (Hajnal, 1965), especially when priority is given to career development or a comfortable lifestyle (Van Bavel, Kok, 2010; Benninghaus, 2014). However, for Morgan (1991), this handling of the timing of marriage and childbearing reflects a normatively approved life-course strategy. Childlessness might also be driven by non-financial considerations: late marriage decreases the span of time during which pregnancy can occur, brings about better knowledge of contraception, and strengthens the likelihood of a commitment to a childless lifestyle (De Jong, Sell, 1977). Later ages at marriage can also lead to a greater likelihood of low fecundity and, for some, a strengthened reluctance to have children (Rowland, 2007). Finally, childlessness can simply be the result of a choice not to have children (Toulemon, 1995), which could lead to what might be called an «involuntary postponement of marriage» since the couple does not feel the same need to marry that those wanting children may feel.

As for the postponement of first birth, it seems that it can be regarded as a consequence of the 1930s economic crisis. Yet is the one-child family reflective of a failure or a choice? It can be a failure if the intention was to have no children or, conversely, to have more children (McLaughlin et al., 1988; Rowland, 2007), but it can also be a choice, as, according to Rebreyend (2003), there can be a desire to have a first child that diminishes for subsequent ones.

What was the role of the First World War and the economic crisis of the 1930s in influencing fertility patterns in Belgium and France during the interwar years? The fertility of the cohorts most affected by the war remained in line with that of the cohorts that preceded them. This lack of apparent impact itself poses a problem. Scholars working on the First World War insist on the trauma it wrought, in particular in terms of loss of births (Héran, 2014). It is therefore possible that the most striking effect was the poor recovery in births and the continuation of the decline in fertility to reach exceptionally low thresholds. Festy (1984) already noted that the completed fertility of the cohorts of women most affected by the war (i.e. those born between 1890 and 1900) was almost not affected and that there was an almost complete recovery in lost births. It is only with the cohorts that followed, those for whom part of their reproductive 
lives took place during the economic crisis, that completed fertility increases. Based on this single indicator, the economic crisis would have an effect opposite to what was expected. In sum, it can only be concluded that the high proportion of childlessness and small families affected more those generations whose childbearing took place during the interwar period, but the indicators do not highlight a strong impact of the crisis; there is no break in trends, and one can only speculate that the crisis may have accentuated these trends.

To deepen our understanding of these issues, it would be worthwhile to undertake further study in two new directions. First, the cohorts that experienced the lowest fertility rates may be socioeconomically characterised, particularly in terms of education levels (Bailey, Brée, 2015), because one can assume that behaviours in response to a crisis situation vary among different social groups. Also, analyses of regional variations may be relevant, as behaviours can also vary according to factors such as patterns of industrialisation and urbanisation, the influence of religion or the urban-rural character.

\section{Bibliography}

Anderson G., Sobolev B. (2013), "Small Effects of Selective Migration and Selective Survival in Retrospective Studies of Fertility", European Journal of Population, 29 (3), pp. 345-354, https://doi.org/10.1007/s10680-013-9293-6.

ANDERSON M. (1998), «Highly Restricted Fertility: Very Small Families in the British Fertility Decline», Population Studies: A Journal of Demography, 52 (2), pp. 177-199.

BARDET J.-P. (1998), "La France : la fin d'une singularité ?», J. R. BARDET, J. DUPÂQUIER (eds), Histoire des populations de l'Europe, Tome 4 : Les temps incertains, 1914-1998, Paris, Fayard, pp. 437-488.

BAILEY M., BRÉE S. (2015), «A Cross-Country Comparison of Fertility Rates and Education: Lessons from 20th Century France and the United States», Paper presented at the Education and reproduction in Low-Fertility Settings Conference (EDUREP), Vienna Institute of Demography, Austria, December.

Bengtsson T., Dribe M. (2014), «The Historical Fertility Transition at the Micro Level: Southern Sweden, 1815-1939», Demographic Research, 30 (17), pp.491-534, https://doi.org/10.4054/demres.2014.30.17.

Benninghaus C. (2014), «'No, Thank You, Mr. Stork!': Voluntary Childlessness in Weimar and Contemporary Germany», Studies in the Maternal, 6 (1), online.

BRÉE S. (2017), "Changes in Family Size over Generations (France, 1850-1966)», Forthcoming in Population, English Edition, 2. 
Brée S., Eggerickx T., SANDerson J.-P., Costa R. (2016a), "Comparison of Retrospective Fertility Data from Censuses in Belgium and Family Surveys in France», Population (English version), 71 (1), pp. 85-120, https://doi.org/10.3917/popu.1601.0085.

Brée S., Eggerickx T., Bourguignon M. (2016b), «La fécondité en Europe Occidentale durant l'entre-deux-guerre. Quels effets des crises sur les comportements démographiques", Annales de Démographie Historique, 2, pp. 41-63.

Cahen F., Minard A. (2015), "Venereal Diseases, Criminal Abortion and Secondary Infertility in France, 1880-1940», Paper presented at the Sex, Disease and Fertility in History Conference, September, Cambridge, England.

Caldwell J. C. (2008), "Three Fertility Compromises and Two Transitions», Population Research Policy Review, 27, pp. 427-446, https://doi.org/10.1007/s11113-0089071-z.

Caldwell J. C., Schindlmayr T. (2003), «Explanations of the Fertility Crisis in Modern Societies: A Search for Commonalities», Population Studies, 57 (3), pp. 241-263.

Cova A. (1997), Maternité et droits des femmes en France (19ème-20ème siècles), Paris, Anthropos, 435 p, https://doi.org/10.1080/0032472032000137790.

DAGUET F. (2002), Un siècle de fécondité française, caractéristiques et évolution de la fécondité de 1901 à 1999, Paris, Insee Résultats, Société 8.

De Jong G. F., Sell R. R. (1977), «Changes in Childlessness in the United States: A Demographic Path Analysis», Population Studies, 31, pp. 129-141, https://doi.org/10. 1080/00324728.1977.10412751.

De LuCA BARUSSE V. (2008), Les familles nombreuses. Une question démographique, un enjeu politique (1880-1940), Rennes, PUR.

DePoID P. (1941), La reproduction nette en Europe depuis les origines de l'État-Civil, Paris.

DORBRITZ J., SCHWARTZ K. (1996), «Kinderlosigkeit in Deutschland-ein Massenphänomen? Analysen zu Erscheinungsformen und Ursachen», Zeitschrift für Bevölkerungswissenschaft, 21, pp. 231-261.

FESTY P. (1979), La fécondité des pays occidentaux de 1870 à 1970, Paris, Cahier de l'Ined, 85.

FESTY P. (1984), «Effets et répercussion de la première guerre mondiale sur la fécondité française», Population, 39 (6), pp. 977-1 010.

FEsty P. (1991), "Vingtième rapport sur la situation démographique de la France», Population, 46 (5), pp. 1 081-1 159.

FrejKa T., SARDon J.-P. (2004), "Childbearing Trends and Prospects in Low-Fertility Countries. A Cohort Analysis», European Studies of Population, 13.

Hagestad G., CAll V. (2007), "Pathways to Childlessness: A Life Course Perspective», Journal of Family Issues, 28, pp. 1 331-1 361. 
Hajnal J. (1965), «European Marriage Patterns in Perspective», D. V. GLASS, D. E. C. EVERSLEY (eds), Population in History, Edward Arnold, London, pp. 101-143.

HÉRAN F. (2014), «Générations sacrifiées : le bilan démographique de la Grande Guerre», Population et Sociétés, 510, INED, avril.

LANDRY A. (1934), La révolution démographique : études et essais sur les problèmes de population, Paris, INED.

LeSthAEghe R. (1995), «The Second Demographic Transition in Western Countries: An Interpretation", K. O. MASON, A.-M. JENSEN (eds), Gender and Family Change in Industrialized Countries, Oxford, Clarendon Press, pp. 17-62.

Mattessich P. W. (1979), "Childlessness and Its Correlates in Historical Perspective: A Research Note», Journal of Family History, 4, pp. 299-307, https://doi.org/10. 1177/036319907900400304.

MC LAREN A. (1990), History of Contraception: From Antiquity to the Present Day, Cambridge, MA, Basil Blackwell.

Mc Laughlin S., Melber B. D., Billy J. O., Zimmerle D. M., Winges L. D., Johnson T. R. (1988), The Changing Life of American Women, Chapell Hill, University of North Carolina Press.

Morgan P. S. (1991), "Late Nineteenth- and Early Twentieth-Century Childlessness», American Journal of Sociology, 97, pp. 779-807, https://doi.org/10.1086/229820.

NeELs K. (2006), Reproductive Strategies in Belgian Fertility, 1960-1990, Centrum voor Bevolkings- en Gezinsstudie, Brussel, Den Haag.

NeELS K. (2010), «Period and Cohort Effects in Belgian Nuptiality and Fertility: 19601990», T. EgGerickX, J.-P. SANderson (dir), Histoire de la Population de la Belgique et de ses territoires, Chaire Quetelet 2005, Centre de Recherche en Démographie, Presses Universitaires de Louvain, Louvain-la-Neuve, pp. 463-488.

Piette V., Gubin E. (2002), "La politique nataliste de l'entre-deux-guerres», M. T. COENEN (ed), Corps de femmes. Sexualité et contrôle social, De Boeck, Bruxelles, pp. 115-129.

POston D. L., TRENT K. (1982), «International Variability in Childlessness: A Descriptive and Analytical Study", Journal of Family Issues, 3, pp. 473-491, https://doi.org/10. 1177/019251382003004004.

Rebreyend A.-C. (2003), "Sexualités vécues. France 1920-1970», Clio 18, Mixité et coéducation, pp. 209-222.

RebreYend A.-C. (2008), Intimités amoureuses, France 1920-1975, Toulouse, PUM.

ROHRBASSER J.-M. (2014), "Introduction. Hécatombe», J.-M. ROHRBASSER (dir), Bouleversements démographiques de la grande guerre, Paris, INED, pp. 9-18.

RowLAND D. (2007), "Historical Trends in Childlessness», Journal of Family Issues, 28 (10), October, pp. 1'311-1'337. 
SARDON J.-P. (1990), «Le remplacement des générations en Europe depuis le début du siècle», Population, 6, pp. 947-968, https://doi.org/10.2307/1533559.

SARDon J.-P., CALOt G. (1997), «La reprise de la fécondité au milieu des années trente, phénomène non perçu des observateurs du temps ?", L'observatoire démographique européen vous informe, 5, Paris.

Schellekens J., Van Poppel F. (2012), "Marital Fertility Decline in the Netherlands: Child Mortality, Real Wages, and Unemployment, 1860-1939», Demography, pp. 965-988.

SCHWARZ K. (1986), "Childlessness in Germany: Past and Present», H. MooRS, J. SCHOORL (eds), Lifestyles, Contraception and Parenthood: Proceedings of a Workshop The Hague, Netherlands Interdisciplinary Demographic Institute, pp. 241-250.

Sовотка T. (2004), Postponement of Childbearing and Low Fertility in Europe, Groningen/Amsterdam, Rijksuniversiteit Groningen/Dutch University Press.

SPENCER G. K. (1983), Childlessness and One-Child Fertility: A Comparative and Historical Analysis of International Data, Unpublished doctoral dissertation, University of California, Berkeley.

SzReter S. (2014), «The Prevalence of Syphilis in England and Wales on the Eve of the Great War: Re-visiting the Estimates of the Royal Commission on Venereal Diseases 1913-1916», Social History of Medicine, 27 (3), pp. 508-529, https://doi.org/10. 1093/shm/hkt123.

ThéBAUd F. (1992), "La grande guerre, le triomphe de la division sexuelle», G.DuBY, Perrot M. (eds), Histoire des femmes en occident, Tome 5 : le 20ème siècle, Paris, Plon, pp. 31-74.

Toulemon L. (1995), "Très peu de couples restent volontairement sans enfant», Population, 50 (4/5), pp. 1 079-1 109.

TOULEMON L. (2001), «Combien d'enfants, combien de frères et sœurs depuis cent ans ?», Population \& Sociétés, 374.

VAluIN J. (1973), "Les générations les plus touchées par la guerre», J. VALLIN (ed), La mortalité par génération en France, depuis 1899, Paris, Éditions de l'INED, Cahier 63 des Travaux et documents, pp. 163-176.

VAN BAVEL J. (2003), «Birth Spacing as a Family Strategy: Evidence from 19th-century Leuven, Belgium», History of the Family, 8, pp. 585-604, https://doi.org/10.1016/j. hisfam.2003.03.001.

VAN BAVEl J. (2010), "Subreplacement Fertility in the West before the Baby Boom: Past and Current Perspectives», Population Studies, 64 (1), pp. 1-18, https://doi.org/ 10.1080/00324720903362806.

Van Bavel J. (2014), "The Mid-Twentieth Century Baby Boom and the Changing Educational Gradient in Belgian Cohort Fertility», Demographic Research, 30, pp. 925962, https://doi.org/10.4054/DemRes.2014.30.33. 
VAN BAVEL J., Кок J. (2004), "Birth Spacing in the Netherlands: The Effects of Family Composition, Occupation, and Religion on Birth Intervals, 1820-1885», European Journal of Population, 20, pp.119-140, https://doi.org/10.1023/B:EUJP. 0000033860.39537.e2.

VAN BAVEl J., Кок J. (2010), «Pioneers of the Modern Life Style? Childless Couples in Early Twentieth Century Netherlands», Social Science History, 34 (1), Spring, pp. 4772.

Van Bavel J., KoK J., Engelen T. (2008), «Hoge kinderloosheid tijdens het interbellum in Nederland. De rol van godsdienst, levensstandaard en economische crisis», I. MAAS, M. H. D. VAN LEEUWEN, K. MANDEMAKERS (eds), Honderdvijftig jaar levenslopen. De Historische Steekproef Nederlandse bevolking. Boekaflevering Mens en Maatschappij, Amsterdam, Amsterdam University Press, pp. 51-80.

\section{Appendices}

Appendix 1.

GDP per capita (1990 Int. GK\$S) in selected European countries, 1900-1955

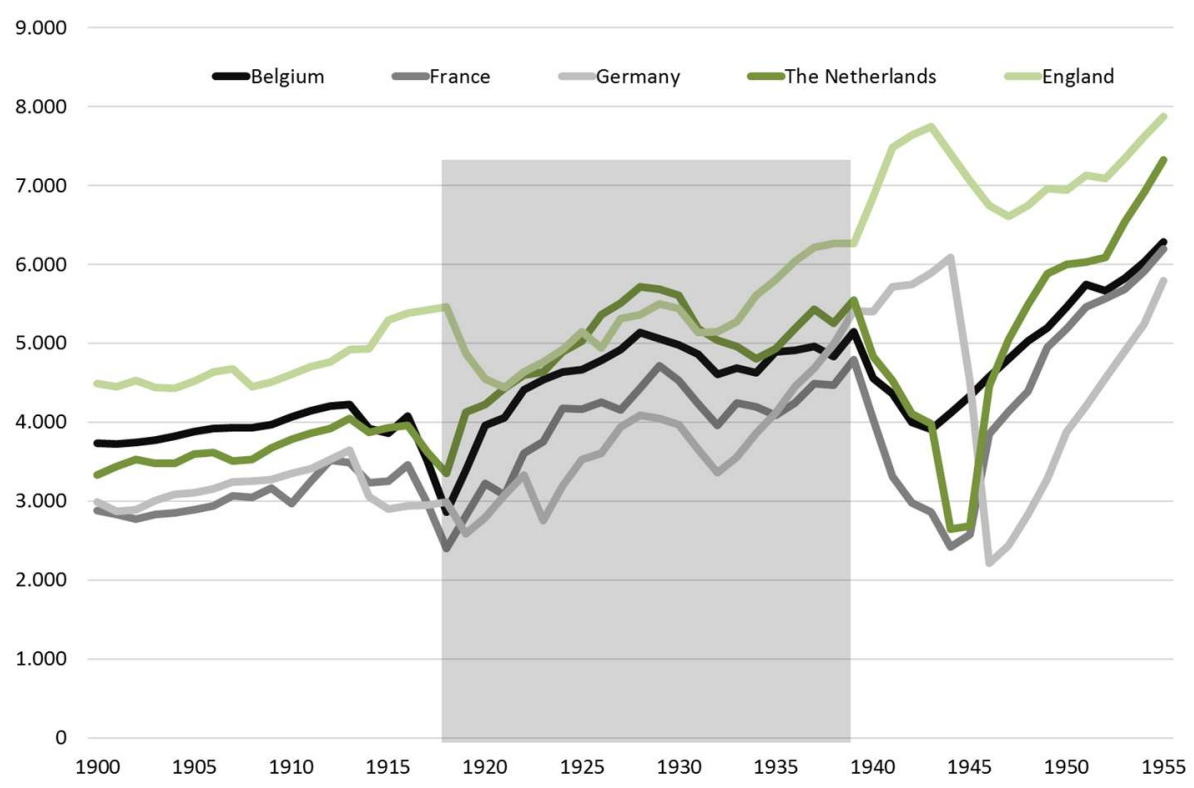

Source: Maddison Project Database: www.ggdc.net/maddison/maddison-project/data.htm. 
Appendix 2. Lowest fertility cohorts in selected European countries

\begin{tabular}{|l|c|c|}
\hline Country & Lowest fertility cohorts & Level \\
\hline Denmark & $1901-1910$ & 2.18 \\
\hline Finland & $1901-1910$ & 2.43 \\
\hline Norway & $1901-1910$ & 2.01 \\
\hline Sweden & $1901-1910$ & 1.84 \\
\hline England-Wales & $1901-1910$ & 1.81 \\
\hline France & $1891-1900$ & 1.98 \\
\hline The Netherlands & $1901-1910$ & 2.81 \\
\hline Switzerland & $1901-1910$ & 1.98 \\
\hline Spain & $1911-1920$ & 2.52 \\
\hline Belgium & $1896-1905$ & 1.88 \\
\hline $\begin{array}{l}\text { Lowest fertility cohort: the cohort that had the lowest lifetime } \\
\text { fertility level. } \\
\text { Source: Festy, 1979, except for Belgium: authors' own calculation. }\end{array}$
\end{tabular}

Appendix 3. Lifetime fertility distribution according to number of children ${ }^{15}$ for ever-married women and all women in Belgium and in France

\begin{tabular}{|c|c|c|c|c|c|c|}
\hline \multicolumn{2}{|l|}{ Belgium } & 0 children & 1 child & 2 children & 3 children & $4+$ children \\
\hline \multirow{4}{*}{$\begin{array}{l}\text { Ever-married } \\
\text { women }\end{array}$} & $1892-96$ & 26.2 & 25.0 & 20.0 & 11.1 & 17.8 \\
\hline & 1897-01 & 25.7 & 25.9 & 19.8 & 11.4 & 17.2 \\
\hline & $1902-06$ & 23.0 & 26.0 & 20.9 & 12.1 & 18.3 \\
\hline & $1907-11$ & 19.2 & 27.2 & 21.7 & 12.7 & 19.2 \\
\hline \multirow{4}{*}{ All women } & $1892-96$ & 26.5 & 24.3 & 19.5 & 11.1 & 18.5 \\
\hline & $1897-01$ & 29.1 & 24.3 & 19.0 & 10.6 & 16.9 \\
\hline & $1902-06$ & 27.7 & 25.0 & 19.4 & 11.0 & 16.9 \\
\hline & $1907-11$ & 26.1 & 24.9 & 19.9 & 11.6 & 17.6 \\
\hline \multicolumn{2}{|l|}{ France } & 0 children & 1 child & 2 children & 3 children & $4+$ children \\
\hline \multirow{4}{*}{$\begin{array}{l}\text { Ever-married } \\
\text { women }\end{array}$} & $1892-96$ & 18.4 & 25.5 & 23.1 & 13.7 & 19.3 \\
\hline & 1897-01 & 17.3 & 25.9 & 23.3 & 13.8 & 19.7 \\
\hline & $1902-06$ & 15.6 & 26.0 & 23.8 & 14.2 & 20.4 \\
\hline & $1907-11$ & 13.9 & 24.4 & 24.4 & 15.4 & 21.9 \\
\hline \multirow{4}{*}{ All women } & $1892-96$ & 26.0 & 23.5 & 20.8 & 12.3 & 17.5 \\
\hline & 1897-01 & 24.9 & 24.0 & 21.1 & 12.4 & 17.7 \\
\hline & $1902-06$ & 22.7 & 24.0 & 21.7 & 13.0 & 18.6 \\
\hline & $1907-11$ & 20.6 & 22.8 & 22.3 & 14.2 & 20.1 \\
\hline
\end{tabular}

15. This takes into consideration all live births. 